\title{
EVALUASI EFEKTIVITAS SISTEM INFORMASI MANAJEMEN DAN AKUNTANSI BARANG MILIK NEGARA ( SIMAK-BMN ) DI DEPARTEMEN KEBUDAYAAN DAN PARIWISATA REPUBLIK INDONESIA
}

\author{
Anggita Kiki Rahardiyanti ${ }^{1}$ \\ BINUS Business School, BINUS University \\ Edi Abdurachman ${ }^{2}$ \\ BINUS Business School, BINUS University
}

\begin{abstract}
The Government obligate to secure BMN. The security include physical security, administrative, and legal secure. In order to secure the necessary administrative administration system that can create a control (controlling) on BMN. Thus the necessary tools in the form of system that can simplify the administration and control of BMN. Management Information Systems and Accounting State Assets (SIMAK-BMN) was organized with the aim to produce the necessary information as a tool of accountability for the implementation of the budget and management / control BMN controlled by an accounting unit of goods. But until now has not carried out an evaluation of the level of keefektivitas SIMAK-BMN especially in the Ministry of Culture and Tourism. Therefore conducted a study to determine the factors that influence the effectiveness of SIMAK-BMN. So this study can be useful for applications maker SIMAK-BMN in knowing what the important factors that must be considered to improve the effectiveness of SIMAK-BMN which have been implemented. The result is that the factors that influence the effectiveness of SIMAKBMN are Facility, Usability and Quality Systems. Without the factors above, it is very unlikely that SIMAK-BMN can operate effectively.
\end{abstract}

Keywords: Effectiveness, Information Systems, SIMAK-BMN, goods belonging to the State.

\footnotetext{
${ }^{1}$ Alumni of BINUS Business School, BINUS University.

${ }^{2}$ Faculty of BINUS Business School, BINUS University (edia@binus.edu).
} 


\begin{abstract}
ABSTRAK
Pemerintah wajib melakukan pengamanan terhadap BMN. Pengamanan tersebut meliputi pengamanan fisik, pengamanan administratif, dan pengamanan hukum. Dalam rangka pengamanan administratif dibutuhkan sistem penatausahaan yang dapat menciptakan pengendalian (controlling) atas BMN. Maka dari itu diperlukan alat bantu berupa system yang dapat mempermudah pengadministrasian serta pengendalian atas BMN. Sistem Informasi Manajemen dan Akuntansi Barang Milik Negara (SIMAK-BMN) diselenggarakan dengan tujuan untuk menghasilkan informasi yang diperlukan sebagai alat pertanggungjawaban atas pelaksanaan APBN serta pengelolaan/pengendalian BMN yang dikuasai oleh suatu unit akuntansi barang. Akan tetapi sampai saat ini belum dilakukan evaluasi mengenai tingkat keefektivitas SIMAK-BMN terutama di lingkungan Departemen Kebudayaan dan Pariwisata. Oleh sebab itu dilakukan penelitian untuk mengetahui faktor-faktor yang mempengaruhi efektivitas dari SIMAK-BMN. Sehingga penelitian ini dapat bermafaat bagi pembuat Aplikasi SIMAK-BMN dalam mengetahui faktor-faktor penting apa saja yang harus lebih diperhatikan untuk meningkatkan efektifitas dari SIMAK-BMN yang telah diimplementasikan. Dari hasil penelitian didapat bahwa faktorfaktor yang berpengaruh terhadap efektifitas SIMAK-BMN adalah Kemudahan, Kegunaan dan Kualitas Sistem. Tanpa adanya faktorfaktor diatas maka sangat kecil kemungkinan SIMAK-BMN dapat beroperasi secara efektif.
\end{abstract}

Kata kunci : Efektivitas, Sistem Informasi, SIMAK-BMN, barang milik Negara.

\title{
PENDAHULUAN
}

Reformasi akuntansi pemerintahan mendapat momentumnya dengan terbitnya 3 (tiga) Undang-Undang yaitu UU Nomor 17 tahun 2003 tentang Keuangan Negara yang mewajibkan adanya suatu Standar Akuntansi Pemerintahaan sebagai basis penyusunan laporan keuangan instansi pemerintah, Undang-Undang Nomor 1 tahun 2004 tentang Perbendaharaan Negara, lalu diperkuat dengan UU Nomor 15 tahun 2004 tentang Pemeriksaan Pengelolaan dan Tanggung Jawab 
Keuangan Negara. Penerbitan PP No.24 tanggal 13 Juni 2005 tentang Standar Akuntansi Pemerintah yang disusun oleh Komite Standar Akuntansi Pemerintah lebih melengkapi paket Undang-Undang Keuangan Negara tersebut

Di dalam UU No. 1 tahun 2004 tentang Perbendaharaan Negara dijelaskan bahwa yang dimaksud barang milik negara adalah semua barang yang dibeli atau diperoleh atas beban APBN dan perolehan lainnya yang sah. Termasuk dalam pengertian perolehan lainnya yang sah, di dalam PP 6 tahun 2006 tentang Pengelolaan BMN/D disebutkan antara lain sumbangan/hibah, pelaksanaan perjanjian/kontrak, ketentuan undang-undang, dan putusan pengadilan.

Pertanggungjawaban atas BMN kemudian menjadi semakin penting ketika pemerintah wajib menyampaikan pertanggungjawaban atas pelaksanaan APBN dalam bentuk laporan keuangan yang disusun melalui suatu proses akuntansi atas transaksi keuangan, aset, hutang, ekuitas dana, pendapatan dan belanja, termasuk transaksi pembiayaan dan perhitungan. Informasi BMN memberikan sumbangan yang signifikan di dalam laporan keuangan (neraca) yaitu berkaitan dengan pos-pos persedian, aset tetap, maupun aset lainnya.

Pemerintah wajib melakukan pengamanan terhadap BMN. Pengamanan tersebut meliputi pengamanan fisik, pengamanan administratif, dan pengamanan hukum. Dalam rangka pengamanan administratif dibutuhkan sistem penatausahaan yang dapat menciptakan pengendalian (controlling) atas BMN. Maka dari itu diperlukan alat bantu berupa sistem yang dapat mempermudah pengadministrasian serta pengendalian atas BMN. Sistem Informasi Manajemen dan Akuntansi Barang Milik Negara (SIMAK-BMN) diselenggarakan dengan tujuan untuk menghasilkan informasi yang diperlukan sebagai alat pertanggungjawaban atas pelaksanaan APBN serta pengelolaan/pengendalian BMN yang dikuasai oleh suatu unit akuntansi barang 


\section{RUMUSAN PERMASALAHAN}

Bertitik tolak dari uraian batasan masalah tesebut di atas, maka rumusan masalah dalam penelitian ini dibatasi pada efektivitas penggunaan SIMAK-BMN oleh para pengguna yang berada di lingkungan Departemen Kebudayaan dan Pariwisata Republik Indonesia.

\section{TINJAUAN TEORI}

Sistem Akuntansi Pemerintah Pusat (SAPP) adalah serangkaian prosedur manual maupun yang terkomputerisasi mulai dari pengumpulan data, pencatatan, pengikhtisaran sampai dengan pelaporan posisi keuangan dan operasi keuangan Pemerintah Pusat. SAPP memiliki 2 (dua) subsistem, yaitu Sistem Akuntansi Bendahara Umum Negara (SA-BUN) dan Sistem Akuntansi Instansi (SAI). SABUN dilaksanakan oleh Departemen Keuangan selaku Bendahara Umum Negara sedangkan Sistem Akuntansi Instansi (SAI) memiliki dua sub sistem: Sistem Akuntansi Keuangan (SAK) dan SIMAKBMN.

SIMAK-BMN merupakan sistem terpadu yang merupakan gabungan prosedur manual dan komputerisasi dalam rangka menghasilkan data transaksi untuk mendukung penyusunan neraca dan juga berguna untuk menunjang fungsi pengelolaan BMN.

Jenis-jenis Transaksi dalam Akuntansi BMN :

\section{Saldo Awal}

Merupakan saldo BMN pada awal tahun anggaran berjalan atau awal tahun mulai diimplementasikannnya SIMAK-BMN yang merupakan akumulasi dari seluruh transaksi BMN tahun sebelumnya.

\section{Perolehan BMN}

Merupakan transaksi penambahan BMN yang tahun tanggal perolehannya sama dengan tahun anggaran berjalan. Transaksi perolehan BMN meliputi:

- Pembelian,

- Transfer Masuk,

- Hibah,

- Rampasan, 
- Penyelesaian Pembangunan,

- Pembatalan Penghapusan,

- Reklasifikasi Masuk

3. Perubahan BMN

- Pelaksanaan dari Perjanjian/Kontrak

Transaksi perubahan BMN meliputi:

- Pengurangan Kuantitas/Nilai,

- Pengembangan,

- Perubahan Kondisi

- Koreksi Perubahan Nilai/Kuantitas,

- Perubahan/ Pengembangan BMN dari penyerahan Aset Tetap Hasil Renovasi,

- Penghentian BMN dari penggunaan aktif,

\section{Penghapusan BMN}

Transaksi penghapusan BMN meliputi:

- Penghapusan,

- Transfer Keluar,

- Hibah,

- Reklasifikasi Keluar,

- Koreksi Pencatatan

\section{METODOLOGI}

Untuk mengetahui efektivitas suatu SIMAK-BMN maka perlu diperhatikan pengaruh antara enam faktor yaitu kualitas SIMAKBMN, kualitas informasi SIMAK-BMN, kegunaan SIMAK-BMN, kemudahan SIMAK-BMN, tingkat pendidikan dan lama penggunaan SIMAK-BMN, dimana jika keenam faktor tersebut mempunyai pengaruh dan hubungan yang positif dalam arti pengguna merasa puas akan SIMAK-BMN dan berpengaruh positif terhadap kinerja departemen maka dapat dikatakan bahwa SIMAK-BMN yang diimplementasikan tersebut bekerja secara efektif. Namun sebaliknya , jika salah satu dari korelasi antara keenam faktor tersebut negatif maka dapat dikatakan bahwa SIMAK-BMN yang diimplementasikan tersebut belum bekerja secara efektif. Berdasarkan model tersebut akan diketahui variabel-variabel yang akan digunakan untuk merumuskan hipotesis-hipotesis yang akan diuji dalam penelitian ini dimana untuk menguji hipotesis-hipotesis tersebut akan digunakan metode statistik Multiple Regressions. 


\section{Variabel Penelitian}

Penelitian ini mempunyai 6 (enam) variabel bebas seperti terlihat pada model efektivitas SIMAK-BMN yaitu :

1. Kualitas SIMAK-BMN (X1)

2. Kualitas informasi yang dihasilkan oleh SIMAK-BMN (X2)

3. Kegunaan dari SIMAK-BMN (X3)

4. Kemudahan penggunaan SIMAK-BMN (X4)

5. Tingkat pendidikan terakhir pengguna (X5)

6. Lama menggunakan SIMAK-BMN (X6)

Kepuasan pengguna terhadap SIMAK-BMN dapat berfungsi sebagai variabel tidak bebas (Y) ataupun sebagai variabel antara. Keenam variabel bebas $(\mathrm{X})$ tersebut berpengaruh signifikan terhadap kepuasan pengguna terhadap SIMAK-BMN (Y) dimana untuk menganalisisnya menggunakan metode statistik Regresi Linear Berganda (Multiple Regression).

Dalam melakukan penelitian ini, populasinya terdiri dari seluruh pengguna SIMAK-BMN baik satuan kerja pusat maupun daerah pada Departemen Kebudayaan dan Pariwisata. Di instansi pusat terdapat 7 (tujuh) satuan kerja sedangkan 49 satuan kerja menyebar di seluruh daerah. Populasi pengguna SIMAK-BMN adalah sebanyak 68 orang pengguna dimana untuk satuan kerja pusat terdapat 15 orang pengguna sedangkan 53 orang pengguna terdapat di satua kerja daerah. Sampel dipilih hanya 1 (satu) orang dari setiap satuan kerja. Jika setiap satuan kerja memiliki lebih dari 1 (satu) pengguna maka yang dipilih adalah pengguna yang paling lama menggunakan SIMAK- BMN. Sampel yang dipilih sebanyak 50 orang pengguna SIMAK-BMN.

Metode yang digunakan dalam pengumpulan data adalah dengan menyebarkan kuesioner kepada para pengguna yang telah disebutkan sebelumnya dalam populasi dan sampel. Kuesioner disebarkan dengan 2 (dua) cara yaitu bagi para pengguna yang berada di kantor pusat maka kuesioner akan dibagikan secara langsung dan dikumpulkan kembali. Sedangkan bagi pengguna yang berada di daerah maka kuesioner akan dikirimkan melalui email atau fax.

Jenis pertanyaan yang digunakan untuk menyusun kuesioner ini adalah pertanyaan tertutup dimana responden hanya dimungkinkan 
untuk menjawab alternatif jawaban yang telah disediakan dalam kuesioner. Hal ini dimaksudkan agar kemungkinan jawaban yang diberikan pengguna menjadi dipersempit dan juga dapat mempermudah pengisian kuesioner.

Sebanyak 50 kuesioner yang akan disebarkan kepada pengguna dimana setiap pilihan jawaban pada tiap-tiap pertanyaan tersebut memiliki bobot dengan skala 1 sampai 5 yang akan digunakan dalam analisa statistic.

\section{HASIL DAN PEMBAHASAN}

Untuk menganalisis pengaruh antara keenam faktor tersebut, penulis menggunakan suatu metode statistik "Korelasi" dan "Regresi Linear Berganda”. Proses pengumpulan data dilakukan dengan teknik menggunakan kuesioner. kepada para pengguna SIMAK-BMN di lingkungan Departemen Kebudayaan dan Pariwisata sebanyak 50 orang pada instansi pusat dan Unit Pelaksanaan Teknis yang tersebar di berbagai daerah. Penyebaran Kuesioner untuk para pengguna SIMAK-BMN yang berada di pusat dilakukan dengan memberikan hardcopy kuesioner secara langsung sedangkan untuk yang di daerah melalui fax dan atau email. Hasil dari kuesioner yang dikembalikan oleh para responden tersebut dianalisis dengan menggunakan program SPSS release 13.0.

Dari sebaran kuesioner diketahui bahwa sebagian besar responden berada pada rentang usia antara 25-35 tahun yaitu sebanyak 21 orang (42\%). Sedangkan untuk jenis kelamin , sebagian besar responden adalah laki-laki yaitu sebanyak 29 orang (58\%). Berdasarkan tingkat Pendidikan responden sebagian besar adalah Pendidikan SMA sebanyak 32 orang ( 64 \%). Untuk lamanya penggunaan SIMAKBMN diketahui bahwa sebagian besar responden menggunakan SIMAK-BMN antara 1 sampai dengan 6 bulan yaitu sebanyak 32 orang $(64 \%)$

\section{Uji Hasil Validitas}

Nilai batas validitas adalah 0,3 untuk masing-masing variabel. Jika nilai validitas lebih besar dari 0,3 maka instrument dinyatakan telah lulus uji validitas, namun jika nilai validitas lebih kecil dari 0,3 maka 
instrument dinyatakan tidak lulus uji validitas. Berikut adalah hasil uji validitas.

Tabel 1. Hasil Uji Validitas Variabel tiap-tiap pertanyaan

\begin{tabular}{|c|c|c|c|}
\hline Variabel & Pertanyaan & Korelasi & Kesimpulan \\
\hline \multirow{5}{*}{$\begin{array}{l}\text { Kualitas } \\
\text { SIMAK-BMN }\end{array}$} & A1 & 0,637 & Valid \\
\hline & A2 & 0,597 & Valid \\
\hline & A3 & 0,246 & Tidak Valid \\
\hline & A4 & 0,439 & Valid \\
\hline & A5 & 0,694 & Valid \\
\hline \multirow{7}{*}{$\begin{array}{l}\text { Kualitas } \\
\text { Informasi } \\
\text { SIMAK-BMN } \\
\end{array}$} & B1 & 0,523 & Valid \\
\hline & B2 & 0,722 & Valid \\
\hline & B3 & 0,685 & Valid \\
\hline & B4 & 0,361 & Valid \\
\hline & B5 & 0,748 & Valid \\
\hline & B6 & 0,628 & Valid \\
\hline & B7 & 0,685 & Valid \\
\hline \multirow{6}{*}{$\begin{array}{l}\text { Kegunaan } \\
\text { SIMAK-BMN }\end{array}$} & C1 & 0,733 & Valid \\
\hline & $\mathrm{C} 2$ & 0,681 & Valid \\
\hline & C3 & 0,666 & Valid \\
\hline & $\mathrm{C} 4$ & 0,821 & Valid \\
\hline & $\mathrm{C} 5$ & 0,559 & Valid \\
\hline & C6 & 0,559 & Valid \\
\hline \multirow{2}{*}{$\begin{array}{l}\text { Kemudahan } \\
\text { Penggunaan } \\
\text { SIMAK-BMN } \\
\end{array}$} & D1 & 0,543 & Valid \\
\hline & $\mathrm{D} 2$ & 0.625 & Valid \\
\hline
\end{tabular}




\begin{tabular}{|l|l|l|l|}
\hline Variabel & Pertanyaan & Korelasi & Kesimpulan \\
\hline & D3 & 0,706 & Valid \\
\hline & D4 & 0,664 & Valid \\
\hline & D5 & 0,072 & Tidak Valid \\
\hline & D6 & 0,551 & Valid \\
\hline $\begin{array}{l}\text { Efektivitas } \\
\text { SIMAK-BMN }\end{array}$ & E1 & 0,593 & Valid \\
\hline & E2 & 0,613 & Valid \\
\hline & E3 & 0,717 & Valid \\
\hline & E4 & 0,477 & Valid \\
\hline & E5 & 0,655 & Valid \\
\hline
\end{tabular}

Dari hasil uji pada table diatas dapat terlihat bahwa ada beberapa pertanyaan dalam kuesioner yang tidak valid, dimana korelasi lebih kecil dari 0,3 maka pertanyaan tersebut akan dibuang dari penelitian ini.

Setelah membuang beberapa pertanyaan yang tidak valid, maka selanjutnya uji validitas kembali dilakukan untuk mendapatkan nilai yang baru. Hasil validitas yang baru dapat dilihat pada table dibawah ini .

Tabel 2. Hasil Uji Validitas Terkoreksi

\begin{tabular}{|l|l|l|l|}
\hline Kualitas SIMAK-BMN & A1 & 0,576 & Valid \\
\hline & A2 & 0,678 & Valid \\
\hline & A4 & 0,552 & Valid \\
\hline & A5 & 0,695 & Valid \\
\hline $\begin{array}{l}\text { Kemudahan } \\
\text { Penggunaan SIMAK- } \\
\text { BMN }\end{array}$ & D1 & 0,631 & Valid \\
\hline & D2 & 0,582 & Valid \\
\hline & D3 & 0,747 & Valid \\
\hline
\end{tabular}




\begin{tabular}{|l|l|l|l|}
\hline & D4 & 0,634 & Valid \\
\hline & & & \\
\hline
\end{tabular}

\section{Uji Hasil Reliabilitas}

Setelah menguji validitas maka dilakukan uji reliabilitas atau kehandalan dari tiap-tiap butir pertanyaan atas variabel pertanyaan yang ada. Hal ini dimaksud untuk melihat konsistensi dari jawabanjawaban responden terhadap setiap butir pertanyaan yang diajukan dimana suatu variabel dikatakan reliable atau handal jika nilai dari $r$ alpha menunjukkan nilai positif dan lebih besar dari 0,7. Berikut merupakan hasil uji reliabilitas setiap variabel dengan menggunakan software statistik SPSS :

Tabel 3. Hasil Uji Reliabilitas Tiap-Tiap pertanyaan

\begin{tabular}{|l|l|l|}
\hline Variabel & $\begin{array}{l}\text { Nilai r } \\
\text { Alpha }\end{array}$ & Kesimpulan \\
\hline Kualitas SIMAK-BMN & 0,800 & reliabel \\
\hline Kualitas Informasi SIMAK-BMN & 0,853 & reliabel \\
\hline Kegunaan SIMAK-BMN & 0,870 & reliabel \\
\hline $\begin{array}{l}\text { Kemudahan Penggunaan SIMAK- } \\
\text { BMN }\end{array}$ & 0,839 & reliabel \\
\hline Efektivitas terhadap SIMAK-BMN & 0,812 & reliabel \\
\hline
\end{tabular}

Berdasarkan hasil uji reliabilitas diatas (setelah item yang tidak valid tidak disertakan), maka didapat nilair alpha tiap-tiap variabel mempunyai hasil positif dan lebih besar dari 0,7 sehingga dapat dikatakan bahwa setiap responden telah memberikan jawabanjawaban secara konsisten.

\section{Regresi dan ANOVA}

Hasil kesimpulan diatas menunjukkan ada 6 (enam) variabel yang berkorelasi dengan efektivitas SIMAK-BMN. Maka ada 6 
(enam)variabel independen yang dimasukan ke dalam regresi, dengan variabel dependen adalah efektivitas SIMAK-BMN.

Namun berdasarkan hasil perhitungan regresi berdasarkan SPSS software, maka didapat bahwa :

- Variabel “Kualitas Informasi” mempunyai signifikan probabilitas sebesar 0.488, dimana hasilnya lebih besar daripada 0.05, sehingga variabel tersebut dapat dihilangkan

- Variabel “Tingkat pendidikan” mempunyai signifikan probabilitas sebesar 0.561, dimana hasilnya lebih besar daripada 0.05 , sehingga variabel tersebut dapat dihilangkan

- Variabel "Lama Penggunaan SIMAK-BMN" mempunyai signifikan probabilitas sebesar 0.068, dimana hasilnya lebih besar daripada 0.05, sehingga variabel tersebut dapat dihilangkan

Hasil pengujian regresi tersebut ditunjukkan dengan tabel dibawah ini

Tabel 4. Hasil Uji Regresi Linear Berganda

\begin{tabular}{|c|c|c|c|c|c|c|}
\hline $\begin{array}{l}\text { M } \\
\text { od } \\
\text { el }\end{array}$ & & $\begin{array}{l}\text { Unstand } \\
\text { ardized } \\
\text { Coeffici } \\
\text { ent }\end{array}$ & & & $\mathrm{t}$ & Sig \\
\hline & & B & Std.Error & beta & & \\
\hline \multirow[t]{7}{*}{1} & (Constant) & 0.480 & 0.531 & & 0.905 & 0.370 \\
\hline & $\mathrm{X} 1$ & -0.350 & 0.130 & -0.300 & -2.343 & 0.024 \\
\hline & $\mathrm{X} 2$ & 0.107 & 0.153 & 0.105 & 0.699 & 0.488 \\
\hline & X3 & 0.633 & 0.141 & 0.634 & 4.498 & 0.000 \\
\hline & $\mathrm{X} 4$ & 0.346 & 0.143 & 0.276 & 2.416 & 0.020 \\
\hline & X5 & 0.036 & 0.062 & 0.057 & 0.586 & 0.561 \\
\hline & $\mathrm{X} 6$ & 0.120 & 0.064 & 0.201 & 1.872 & 0.068 \\
\hline
\end{tabular}

Setelah dilakukan tes regresi terdapat 3 (tiga) variabel yang mempunyai koefisien korelasi lebih besar dari 0,05 yaitu variabel 
kualitas informasi (X2), tingkat pendidikan pengguna (X5), dan lama penggunaan SIMAK-BMN (X6).

Maka dari itu variabel tersebut dapat dihilangkan sehingga persamaan regresi yang didapat dari hasil penelitian adalah :

$$
Y=0,480+0,024(X 1)+0,000(X 3)+0,020(X 4)
$$

Tabel 5. ANOVA

\begin{tabular}{|l|c|c|c|c|c|}
\hline \multicolumn{1}{|c|}{ Model } & $\begin{array}{c}\text { Sum of } \\
\text { Squares }\end{array}$ & Df & $\begin{array}{c}\text { Mean } \\
\text { Square }\end{array}$ & F & Sig \\
\hline Regression & 7,568 & 6 & 1,261 & 11,558 & $0,000^{\text {a }}$ \\
\hline Residual & 4,692 & 43 & 0,109 & & \\
\hline Total & 12,260 & 49 & & & \\
\hline
\end{tabular}

Dari Tabel ANOVA diatas didapatkan bahwa nilai $\mathrm{F}$ hitung sebesar 11,558 dengan nilai signifikansi $\left(0,000^{\mathrm{a}}\right)$ jauh lebih kecil daripada 0,05. Hal ini berarti minimal terdapat satu variabel dari keenam variabel yang mempengaruhi efektivitas SIMAK-BMN

Tabel 6. Nilai $\mathrm{R}, \mathrm{R}^{2}$ dan adjusted $\mathrm{R}^{2}$

\begin{tabular}{|l|c|c|c|c|}
\hline \multicolumn{1}{|c|}{ Model } & $\mathrm{R}$ & R Square & $\begin{array}{c}\text { Adjusted } \\
\text { R Square }\end{array}$ & $\begin{array}{c}\text { Std.Error of } \\
\text { the } \\
\text { Estimate }\end{array}$ \\
\hline 1 & $0,786^{\mathrm{a}}$ & 0,617 & 0,564 & 0,33034 \\
\hline
\end{tabular}

a. Predictors : (Constant), X6,X4,X5,X3,X2,X1

Dari tabel diatas diketahui bahwa dengan Adjusted $\mathrm{R}$ square sebesar 0.564 yang berarti ketiga variable ( X1, X3, X4) memberikan kontribusi 56,4\% kepada efektivitas SIMAK-BMN. Sedangkan sisanya sebesar 43,6 \% dipengaruhi atau disebabkan oleh faktor lain. 


\section{Pengujian Hipotesis}

Dari data yang diperoleh dari responden , maka dilakukan perhitungan untuk menguji hipotesis-hipotesis yang telah dibuat sebagai berikut :

\section{Hipotesis 1}

$\mathrm{H}_{\mathrm{O}}$ : Tidak ada pengaruh faktor kualitas, kualitas informasi, kegunaan, kemudahan penggunaan, tingkat pendidikan, lama penggunaan SIMAK-BMN terhadap efektivitas atas SIMAK-BMN

$\mathrm{H}_{1}$ : Terdapat minimal satu dari faktor kualitas, kualitas informasi, kegunaan, kemudahan penggunaan, tingkat pendidikan, lama penggunaan SIMAK-BMN terhadap efektivitas atas SIMAKBMN.

Berdasarkan hasil perhitungan dengan Uji $\mathrm{F}$ dari program aplikasi SPSS maka didapat bahwa bahwa nilai signifikan sangat kecil yaitu $0,000^{\mathrm{a}}$ dan dibawah nilai $\mathrm{F}(11,558)$ sehingga Ho ditolak dan $\mathrm{H}_{1}$ diterima . Jadi minimal satu dari faktor kualitas, kualitas informasi, kegunaan, kemudahan penggunaan, tingkat pendidikan, lama penggunaan SIMAK-BMN terhadap efektivitas atas SIMAK-BMN.

\section{Hipotesis 2}

$\mathrm{H}_{\mathrm{O}}$ : Tidak ada pengaruh faktor kualitas SIMAK-BMN terhadap efektivitas atas SIMAK-BMN.

$\mathrm{H}_{1}$ : Ada pengaruh faktor kualitas SIMAK-BMN terhadap efektivitas atas SIMAK-BMN.

Berdasarkan hasil perhitungan dari program aplikasi SPSS maka didapat bahwa faktor Kualitas SIMAK-BMN mempunyai signifikan probabilitas sebesar 0.024,dimana hasilnya lebih kecil daripada 0.05(dengan taraf kepercayaan 95\%) sehingga Ho ditolak dan H1 diterima. Jadi ada pengaruh yang signifikan antara Kualitas SIMAKBMN terhadap Efektivitas SIMAK-BMN.

\section{Hipotesis 3}

$\mathrm{H}_{\mathrm{O}}$ : Tidak ada pengaruh faktor kualitas informasi yang dihasilkan oleh SIMAK-BMN terhadap efektivitas atas SIMAK-BMN.

$\mathrm{H}_{1}$ : Ada pengaruh faktor kualitas informasi yang dihasilkan oleh SIMAK-BMN terhadap efektivitas atas SIMAK-BMN.

Berdasarkan hasil perhitungan dari program aplikasi SPSS maka didapat bahwa faktor Kualitas Informasi SIMAK-BMN mempunyai signifikan probabilitas sebesar 0.488, dimana hasilnya lebih besar daripada 0.05 ( dengan taraf kepercayaan 95\%) sehingga Ho diterima 
dan H1 ditolak. Jadi tidak ada pengaruh yang signifikan antara Kualitas Informasi yang dihasilkan SIMAK-BMN terhadap Efektivitas SIMAK-BMN.

\section{Hipotesis 4}

$\mathrm{H}_{\mathrm{O}}$ : Tidak ada pengaruh faktor kegunaan dari SIMAK-BMN terhadap efektivitas atas SIMAK-BMN.

$\mathrm{H}_{1}$ : Ada pengaruh faktor kegunaan dari SIMAK-BMN terhadap efektivitas atas SIMAK-BMN

Berdasarkan hasil perhitungan dari program aplikasi SPSS maka didapat bahwa faktor Kegunaan SIMAK-BMN mempunyai signifikan probabilitas sebesar 0.000 , dimana hasilnya lebih kecil daripada 0.005 (dengan taraf kepercayaan 95\%) sehingga Ho ditolak dan H1 diterima. Jadi ada pengaruh yang signifikan antara Kegunaan SIMAK-BMN terhadap Efektivitas SIMAK-BMN.

\section{Hipotesis 5}

$\mathrm{H}_{\mathrm{O}}$ : Tidak ada pengaruh faktor kemudahan penggunaan SIMAKBMN terhadap efektivitas atas SIMAK-BMN.

$\mathrm{H}_{1}$ : Ada pengaruh faktor kemudahan penggunaan SIMAK-BMN terhadap efektivitas atas SIMAK-BMN.

Berdasarkan hasil perhitungan dari program aplikasi SPSS maka didapat bahwa faktor Kemudahaan Penggunaan SIMAK-BMN mempunyai signifikan probabilitas sebesar 0.020, dimana hasilnya lebih kecil daripada 0.05 ( dengan taraf kepercayaan 95\%) sehingga Ho ditolak dan H1 diterima. Jadi ada pengaruh yang signifikan antara Kemudahan Penggunaan SIMAK-BMN terhadap Efektivitas SIMAK-BMN.

\section{Hipotesis 6}

$\mathrm{H}_{\mathrm{O}}$ : Tidak ada pengaruh faktor tingkat pendidikan terakhir pengguna terhadap efektivitas atas SIMAK-BMN.

$\mathrm{H}_{1}$ : Ada pengaruh faktor tingkat pendidikan terakhir pengguna terhadap efektivitas atas SIMAK-BMN.

Berdasarkan hasil perhitungan dari program aplikasi SPSS maka didapat bahwa variabel tingkat pendidikan mempunyai signifikan probabilitas sebesar 0.561, dimana hasilnya lebih besar daripada 0.05 (dengan taraf kepercayaan 95\%) sehingga Ho diterima dan H1 ditolak. Jadi tidak ada pengaruh yang signifikan antara tingkat pendidikan terakhir responden terhadap Efektivitas SIMAK-BMN. 


\section{Hipotesis 7}

$\mathrm{H}_{\mathrm{O}}$ : Tidak ada pengaruh faktor lama penggunaan SIMAK-BMN terhadap efektivitas atas SIMAK-BMN.

$\mathrm{H}_{1}$ : Ada pengaruh faktor lama penggunaan SIMAK-BMN terhadap efektivitas atas SIMAK-BMN.

Berdasarkan hasil perhitungan dari program aplikasi SPSS maka didapat bahwa faktor lama penggunaan SIMAK-BMN mempunyai signifikan probabilitas sebesar 0.068, dimana hasilnya lebih besar daripada 0.05 ( dengan taraf kepercayaan 95\%) sehingga Ho diterima dan $\mathrm{H} 1$ ditolak. Jadi tidak ada pengaruh yang signifikan antara lamanya penggunaan SIMAK-BMN terhadap Efektivitas SIMAKBMN.

\section{Pembahasan Hasil Penelitian}

Berdasarkan hasil analisis yang telah dilakukan sebelumnya ditemukan bahwa dari 6 (enam) variabel yang digunakan dalam model penelitian terdapat 3 (tiga) variabel yang mempunyai pengaruh yang signifikan pada efektivitas SIMAK-BMN. Variabel-variabel independen yang mempunyai pengaruh yang signifikan tersebut adalah kualitas SIMAK-BMN, kegunaan SIMAK-BMN ,dan kemudahan penggunaan SIMAK-BMN. Sementara variabel yang tidak mempunyai pengaruh yang signifikan adalah kualitas informasi SIMAK-BMN, tingkat pendidikan pengguna SIMAK-BMN dan lama penggunaan SIMAK-BMN. Berikut ini adalah pembahasan dari masing-masing variabel yang mempunyai pengaruh signifikan terhadap efektivitas SIMAK-BMN.

\section{Varibel Kualitas SIMAK-BMN}

Berdasarkan data yang didapatkan dari hasil penelitian, kualitas SIMAK-BMN dengan $\rho$-value sebesar 0,024 mempunyai pengaruh yang signifikan terhadap Efektivitas SIMAK-BMN. Dari informasi yang didapatkan melalui sebaran survey, para pengguna akan merasa puas jika modul atau panduan mengenai SIMAK-BMN dapat diperoleh dengan mudah dan lengkap, waktu respon pengoperasiannya dapat berlansung dengan cepat, minimnya terjadinya kesalahan atau error dan mudahnya mempelajari fungsi/tombol dalam SIMAK-BMN tersebut. Akan tetapi dalam kenyataannya, banyak pengguna merasa tidak puas terutama karena sering terjadinya kesalahan atau error dalam penggunaan SIMAKBMN sehingga mengganggu mereka dalam pelaksanaan tugasnya. 
Jika hal tersebut dapat diperbaiki maka akan terjadi peningkatan terhadap kualitas SIMAK-BMN dan kesalahan atau error yang terjadi dapat diminimalisir

\section{Variabel Kegunaan SIMAK-BMN}

Hasil dari penelitian yang diperoleh menunjukkan bahwa sebagian besar pengguna berpendapat bahwa SIMAK-BMN sangat berguna. Hal ini sesuai dengan data penelitian dimana sebagian pengguna merasa puas dan yakin bahwa SIMAK-BMN berguna dalam membantu menangani barang milik Negara karena SIMAK-BMN mempermudah dan mempercepat pekerjaan mereka. Sehingga diharapkan kegunaan dari SIMAK-BMN dapat terus meningkat dan akhirnya dapat meningkatkan pula Efektivitas SIMAK-BMN.

\section{Variabel Kemudahan Penggunaan SIMAK-BMN}

Dari data penelitian yang diperoleh, menunjukkan bahwa SIMAK sangat mudah digunakan dalam penanganan barang milik Negara. Akan tetapi hal itu juga perlu didukung dengan pelatihan yang intensif yaitu berupa bimbingan teknis pengoperasian SIMAK-BMN karena dalam kenyataannya para pengguna tidak bisa jika hanya mengandalkan buku panduan atau modul yang diberikan. Diharapkan kemudahaan penggunaan SIMAK-BMN dapat terus meningkat dan akhirnya dapat meningkatkan pula efektivitas SIMAK-BMN

Sementara untuk 3 (tiga) variabel independen yang tidak mempunyai pengaruh yang signifikan terhadap efektivitas SIMAK-BMN dapat dijelaskan sebagai berikut :

\section{Variabel Kualitas Informasi SIMAK-BMN}

Karena para pengguna SIMAK-BMN berada pada level pelaksana (operator) , mereka tidak dituntut untuk menganalisa informasi yang dihasilkan sehingga mereka kurang menyadari apakah informasi tersebut berkualitas atau tidak. Oleh sebab itu kualitas informasi SIMAK-BMN tidak terlalu signifikan dalam mempengaruhi efektivitas SIMAK-BMN.

\section{Variabel Tingkat Pendidikan}

Tingkat pendidikan terakhir sebagian besar para pengguna SIMAKBMN adalah SMA. Akan tetapi hal tersebut tidak mempunyai pengaruh yang signifikan terhadap efektivitas SIMAK-BMN karena dengan adanya pelatihan yang intensif dan efektif maka para 
pengguna tersebut dapat mengaplikasikan SIMAK-BMN dengan baik.

\section{Variabel Lama Penggunaan SIMAK-BMN}

Hampir sebagian besar para pengguna mengunakan SIMAK-BMN antara 1-6 bulan lamanya. Jika para penggunanya dapat memahami dan mengerti dengan pengoperasian SIMAK-BMN melalui pelatihan yang diberikan maka dapat dikatakan bahwa lama penggunaan SIMAK-BMN tidak mempunyai pengaruh yang signifikan terhadap efektivitias SIMAK-BMN.

\section{KESIMPULAN DAN SARAN}

\section{Kesimpulan}

Dari hasil penelitian ini ditemukan bahwa :

- Critical success faktor diatas berpengaruh ( 56,4\%) terhadap sukses tidak-nya Efektivitas SIMAK-BMN

- Dari keenam faktor yang diduga mempengaruhi Efektivitas SIMAK-BMN , didapatkan hanya ada 3 (tiga) faktor yang secara signifikan mempengaruhi Efektivitas SIMAK-BMN, yaitu : Kegunaan Sistem, Kemudahan Sistem dan Kualitas Sistem. Ketiga faktor lainnya, yaitu faktor Kualitas Informasi, Lama Penggunaan SIMAK-BMN dan Tingkat Pendidikan tidak mempengaruhi secara signifikan.

- Dari ketiga faktor diatas, faktor Kegunaan Sistem memiliki koefisien yang paling besar, berikutnya faktor Kemudahan Sistem memiliki koefisien terbesar kedua, dan yang terakhir faktor kualitas sistem dalam Efektivitas SIMAK-BMN.

\section{Saran}

- Untuk penelitian selanjutnya ,dapat diteliti lebih lanjut faktorfaktor lain selain keenam faktor dalam penelitian ini, yang mempunyai hubungan dengan Efektivitas SIMAK-BMN misalnya aksesibilitas atau tersedianya peralatan komputer yang memadai

- Perlu diberikan pengenalan atau pelatihan yang intensif kepada para pengguna SIMAK-BMN sebelum mereka mengaplikasikan sistem ini sehingga kesalahan dalam penggunaan SIMAK-BMN dapat diminimalisir

- Bagi pembuat program SIMAK-BMN diharapkan dapat 
menambah karakteristik dan klasifikasi aset milik negara terutama sekali aset bersejarah sehingga satuan kerja yang memiliki aset bersejarah tidak mengalami kesulitan dalam menginventarisir asetnya ke dalam SIMAK-BMN

\section{DAFTAR PUSTAKA}

Sarwono, Jonathan., 2006, Analisis Data Penelitian Menggunakan SPSS, Andi, Yogyakarta.

Levin, Richard I.and Rubin, David S., 1994, Statistics for Management, Sixth Edition, Prentice Hall, New Jersey.

Remenyi, D., Money A. And Twite A., 1995, Effective Measurement \& Management of Information Technology Cost \& Benefit, Butterworth-Heinemann Ltd. British.

Whitten, Jeffery L. ; Bentley, Lonnie D. And Dittman, Kevin C., 2004, Sistem Analysis and Design Methods, 6th edition, Mc.Graw-Hill, New York.

Sugiyono, 2001., Metode Penelitian Bisnis, CV.Alfabeta, Bandung

Delone, W and Mc.Lean, E.1992. Information Sistems Research, [Online] Available: http://www.homepages.ius.edu/BARB/i300/DeloneMcleanten yearupdate.pdf

Laudon, Kenneth C. And Jane P., 1994, Management Information Sistem, Prentice Hall of India Pvt Ltd.

Northcraft, G.B., and Neale, M.A., 1994, Negotiating Successfull Research Collaboration, Prentice Hall, New Jersey.

Weber, Ron., 1999, Information Sistem Control and Audit, Prentice Hall, New Jersey.

Departemen Keuangan Republik Indonesia., 2008, Modul Sistem Akuntansi Pemerintah Pusat. 
Departemen Keuangan Republik Indonesia., 2008, Modul at.

“Undang Undang No. 17 Tahun 2003”. Jakarta. Bina Aksara.

“Peraturan Pemerintah No. 24 Tahun 2005”. Jakarta.Salemba Empat.

"Peraturan Menteri Keuangan Republik Indonesia

No.59/PMK.06/2005”. Jakarta.

128) Rahardiyanti,A.K. \& Edi A./Journal of Applied Finance and Accounting 5(1),110-128 